\title{
Synthesis and thermal behavior of linear neryl diesters in inert and oxidative atmosphere
}

\author{
Marta Worzakowska $\cdot$ Piotr Ścigalski
}

Received: 24 February 2013/Accepted: 2 August 2013/Published online: 29 August 2013

(C) The Author(s) 2013. This article is published with open access at Springerlink.com

\begin{abstract}
The studies on the synthesis and thermal properties of linear neryl diesters were presented. The linear neryl diesters can be successfully obtained during butylstannoic catalyzed esterification process. The final conversion of nerol and carboxylic groups was higher than $95 \%$ using a stoichiometric molar ratio of reagents in mild conditions. The high yield products were prepared after longer time than previously studied geranyl diesters. It was directly connected with the steric hindrance and lower susceptibility of nerol to esterification process than geraniol. The TG/FTIR/QMS studies proved that the thermal properties and decomposition mechanism of neryl diesters differ considerably in inert and oxidative atmosphere. The diesters were thermally stable up to $200{ }^{\circ} \mathrm{C}$ in inert atmosphere. Their decomposition was run as a one-step process. The analyses of the volatile products emitted during their pyrolysis indicated on the ester and O-neryl bonds cleavage. It resulted in the formation of monoterpene hydrocarbons, cyclic acid anhydrides, ketones, or aldehydes. However, the studied compounds were less thermally stable in air than in helium. Their decomposition happened in two steps. The first step ranges from $185-228{ }^{\circ} \mathrm{C}$ to almost $326-380{ }^{\circ} \mathrm{C}$ with mass loss above $88 \%$. The formation of acyclic or alicylic monoterpene hydrocarbons, cyclic acid anhydrides, ketones, alkenes, alkanes, carbon dioxide, and water was expected. It indicated on the asymmetrical distrupt of the bonds, partial oxygenation, and decarboxylation of emitted gaseous fragments. The second step of decomposition was observed in temperatures ranges from
\end{abstract}

M. Worzakowska $(\bowtie) \cdot$ P. Ścigalski

Department of Polymer Chemistry, Faculty of Chemistry,

Maria Curie-Skłodowska University, Gliniana 33 street,

20-614 Lublin, Poland

e-mail: marta.worzakowska@ poczta.umcs.lublin.pl
380 to above $560{ }^{\circ} \mathrm{C}$. In this step carbon dioxide and water were mainly emitted. It was the result of the oxidation of the residue formed during the fist step.

Keywords Linear neryl diesters · TG/FTIR-coupled method . Thermal degradation $\cdot$ Mechanism of thermal degradation

\section{Introduction}

Methods of thermal analysis are incredibly useful tool which helps characterize the thermal behavior of many materials such as organic, inorganic, or polymer products [1-3]. The thermal methods allow the specification of the characteristic temperatures and mass loss during decomposition. They enable to study of the course of pyrolysis or oxidation processes as well as the evaluation of mechanism of decomposition/degradation of various compounds. In addition, the connection of thermogravimetric analysis with the spectroscopic methods like FTIR or/and QMS permits to identify all volatile components which are released during heating. It helps to define the mechanism of decomposition of materials or their degradation kinetics [4-8]. The literature describes the thermal behavior and the mechanism of decomposition of many compounds like polymers [9-15], salts of metals [16-20], proteins [21, 22], monomers, terpenes, esters, raw products, or others [23-26]. However, to this time a less information is accessible on the thermal decomposition mechanism of terpene esters.

Terpene esters are organic, flavor compounds which are used in many industrial applications. They are utilized as components of many flavor and fragrance compositions. They are added to many detergents, daily products, food, tobaccos, and medical products. Also, those esters, 
especially slowly hydrolizable diesters of allylic perfume alcohols like geraniol, nerol, or citronellol may be used as additives in high temperature processing. Due to this, the knowledge of their thermal stability, evaporation, and mechanism of decomposition is necessary. Recently, we have presented the studies on the butylstannoic catalyzed synthesis, thermal behavior and the mechanism of decomposition of geranyl diesters in inert atmosphere [27]. Due to the promising results, we have decided to continue our studies on the synthesis of flavor diesters derivatives of allylic terpene alcohols and their thermal behavior. In those studies, as an allylic terpene alcohol-nerol was applied. Nerol is the cis-isomer of geraniol. It was found in 1902 year in neroli oil in which it occurs principally as acetate

Table 1 The final conversion of nerol and carboxylic groups

\begin{tabular}{lcll}
\hline Diester & $\begin{array}{l}\text { Reaction } \\
\text { time/h }\end{array}$ & $\begin{array}{l}\text { Conversion } \\
\text { of nerol/\% }\end{array}$ & $\begin{array}{l}\text { Conversion of } \\
\text { carboxylic groups/\% }\end{array}$ \\
\hline Dineryl succinate & 8 & 98.0 & 97.5 \\
Dineryl glutarate & 10 & 97.5 & 96.8 \\
Dineryl adipinate & 13 & 97.2 & 96.5 \\
Dineryl sebacinate & 17 & 96.8 & 95.2 \\
\hline
\end{tabular}

${ }^{\mathrm{a}}$ Final conversion of nerol calculated from ${ }^{1} \mathrm{H}$ NMR spectra

${ }^{b}$ Final conversion of carboxylic groups estimated based on residual acid content

Table 2 Physical properties of linear neryl diesters

\begin{tabular}{lcccc}
\hline Properties & $\begin{array}{l}\text { Dineryl } \\
\text { succinate }\end{array}$ & $\begin{array}{l}\text { Dineryl } \\
\text { glutarate }\end{array}$ & $\begin{array}{l}\text { Dineryl } \\
\text { adipinate }\end{array}$ & $\begin{array}{l}\text { Dineryl } \\
\text { sebacinate }\end{array}$ \\
\hline Viscosity $/ \mathrm{mPa} \mathrm{s}^{-3}$ & 13.0 & 16.5 & 26.8 & 38.0 \\
Density $/ \mathrm{g} \mathrm{cm}^{-3}$ & 0.9850 & 0.9920 & 0.9970 & 1.0020 \\
Refractive index & 1.4850 & 1.4862 & 1.4855 & 1.4860 \\
\hline
\end{tabular}

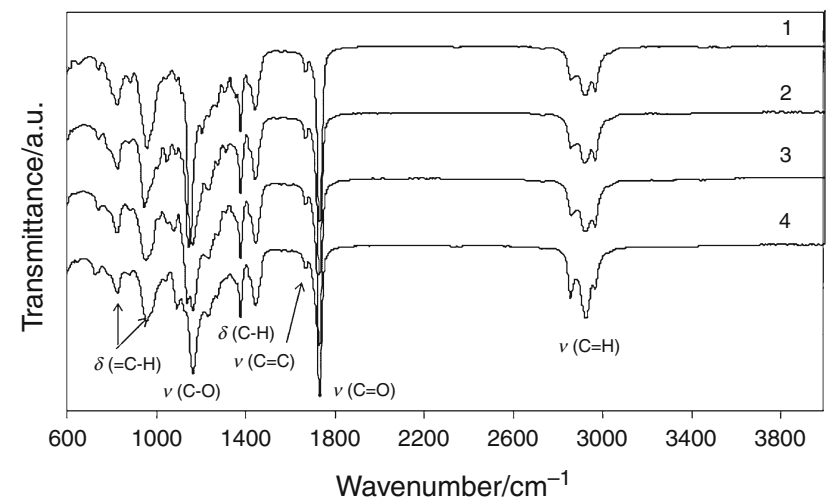

Fig. 1 FTIR spectra of dineryl succinate (1), dineryl glutarate (2), dineryl adipinate (3), and dineryl sebacinate (4)
$[28,29]$. It is also present in the oils of petitgrain, rose, Mexican lignaloes, and Helichrysum angustifolium. Nerol is a coloreless liquid with sweet rose odor fresher than geraniol.

In this work synthesis, characterization, and thermal behavior of linear neryl diesters: dineryl succinate, dineryl glutarate, dineryl adipinate, and dineryl sebacinate were presented. The thermal stability and the decomposition<smiles>[B]/C(C)=C/CC/C=C(/[B])CCC(=O)OCC/C=C(/C)CCC=C(C)C</smiles>

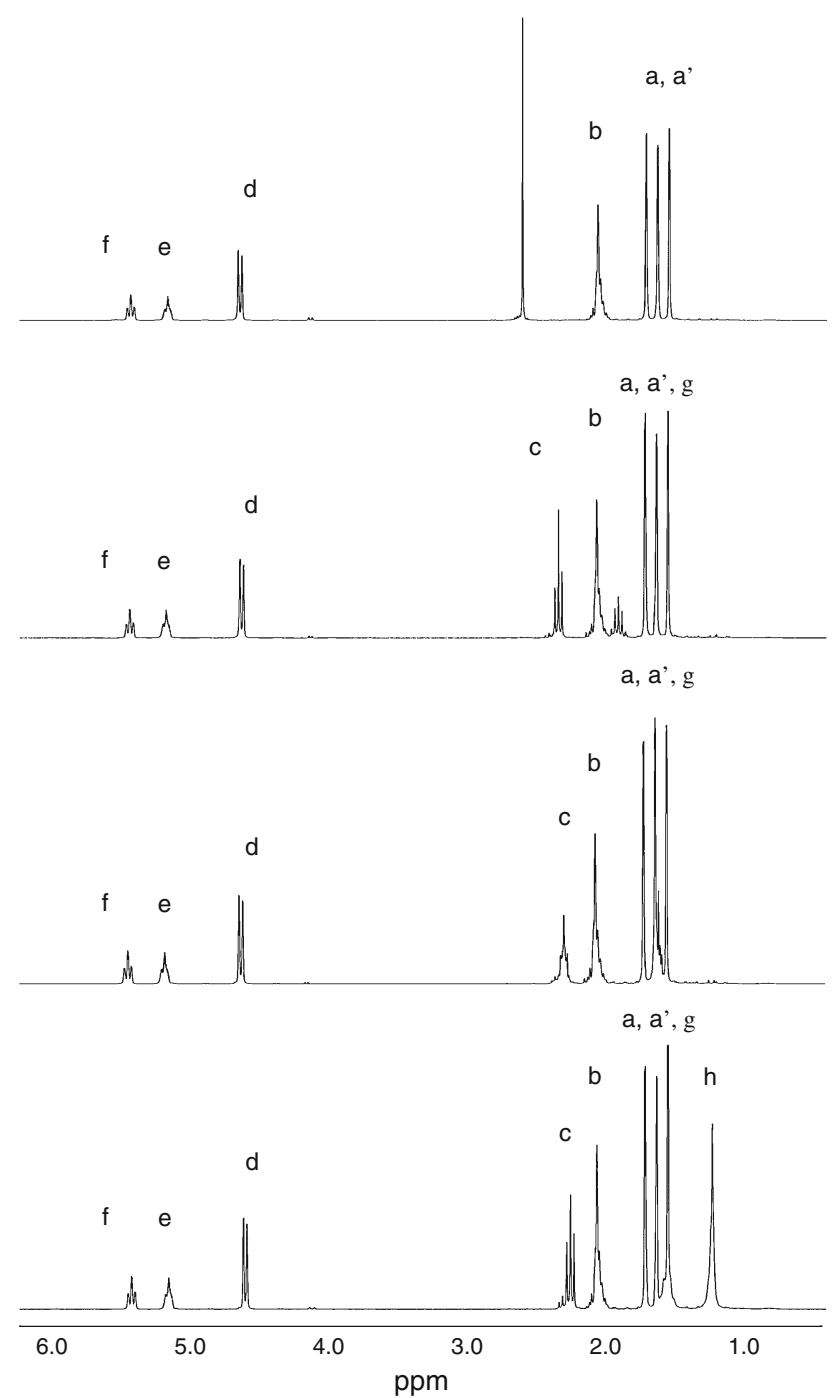

Fig. $2{ }^{1} \mathrm{H}$ NMR spectra of dineryl succinate (1), dineryl glutarate (2), dineryl adipinate (3), and dineryl sebacinate (4) 

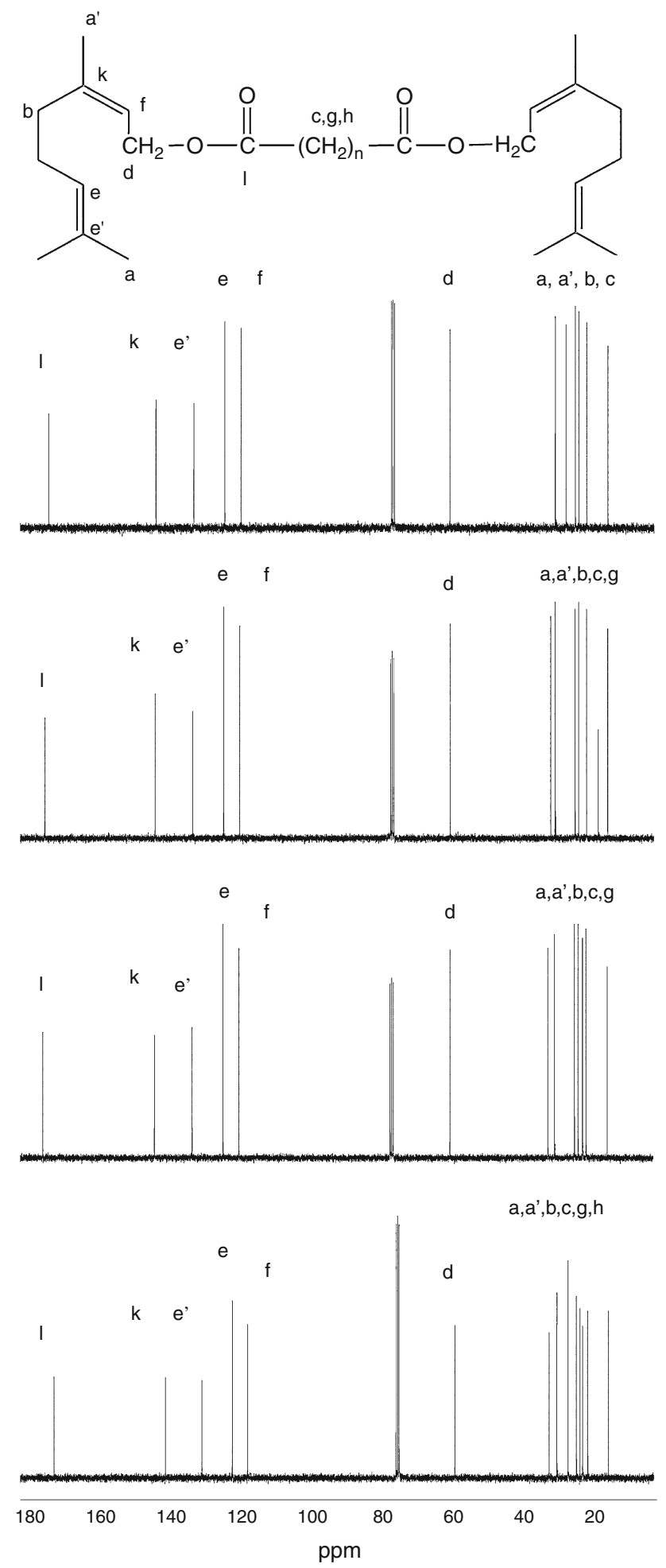

Fig. $3{ }^{13} \mathrm{C}$ NMR spectra of dineryl succinate (1), dineryl glutarate (2), dineryl adipinate (3), and dineryl sebacinate (4)

mechanism of flavor compounds were evaluated based on the TG/FTIR/QMS-coupled method in inert and oxidative atmosphere.
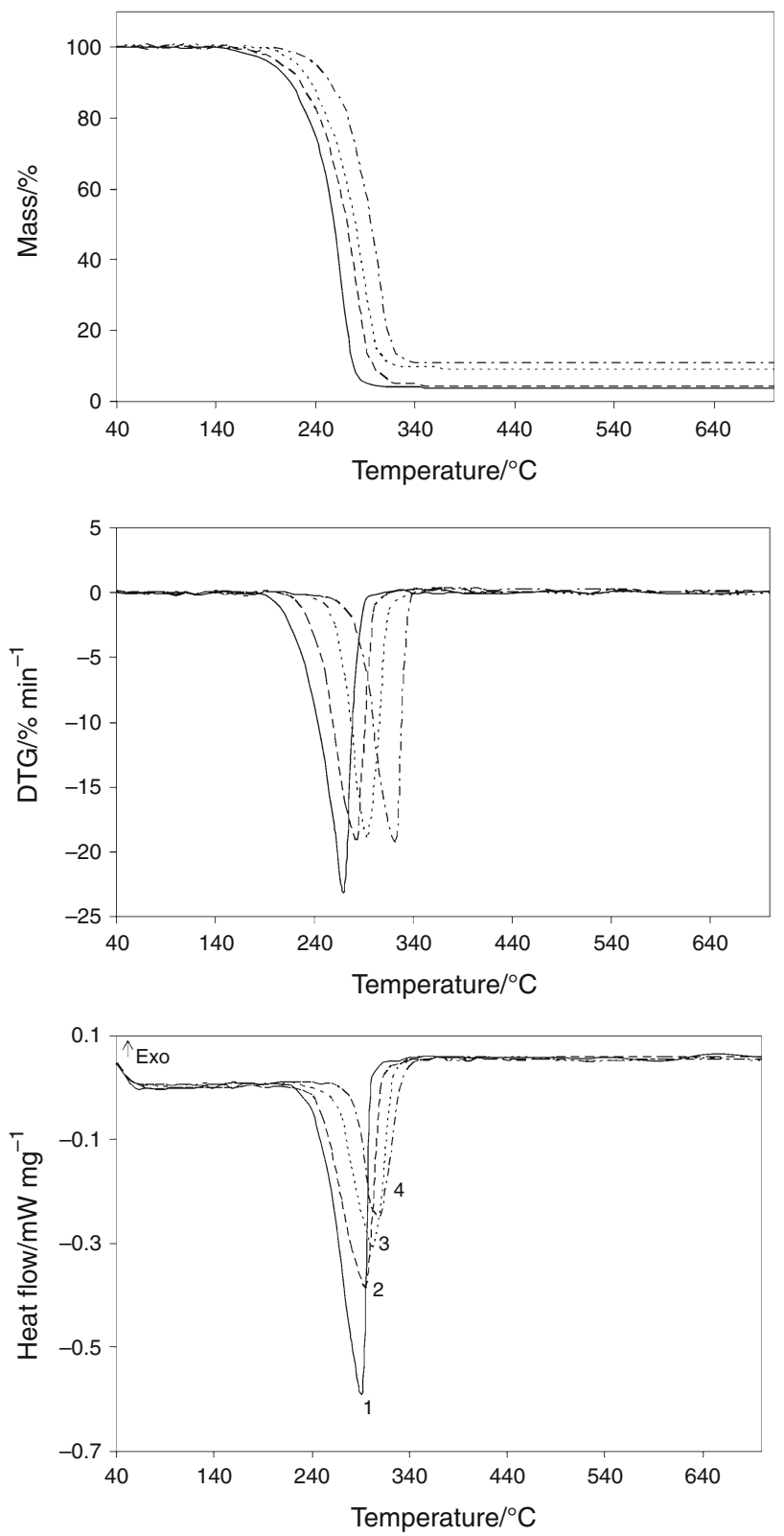

Fig. 4 TG, DTG and DSC curves in inert atmosphere for linear neryl diesters: dineryl succinate (1), dineryl glutarate (2), dineryl adipinate (3), dineryl sebacinate (4)

\section{Experimental}

\section{Materials}

Nerol (cis-3,7-dimethyl-2,6-octadien-1-ol, $97 \%$ ) and glutaric anhydride $(95 \%)$ were purchased from Fluka. Succinic anhydride (99\%), adipic acid (99\%), and sebacic acid $(98 \%)$ were from Merck. Butylstannoic acid (catalyst) was obtained from Arkema Inc., USA. The reagents were used without further purification. 
Synthesis of linear neryl diesters

The neryl diesters were prepared according to procedure previously described [27]. The stoichiometric molar ratio of nerol $(2 \mathrm{~mol})$ and $1 \mathrm{~mol}$ of suitable acidic reagent: acid anhydride (succinic anhydride or glutaric anhydride) or dicarboxylic acid (adypic acid or sebacic acid) was used.

The progress of the reaction was monitored by the determination of the residual acid content and by estimation of ${ }^{1} \mathrm{H}$ NMR spectra. The percentage conversion of carboxylic groups into ester was calculated as being equivalent to acid consumed. The percentage conversion of nerol into ester was evaluated based on ${ }^{1} \mathrm{H}$ NMR spectra. The integration values of methylene protons of nerol $(\delta=4.10 \mathrm{ppm})$ and methylene protons of neryl diesters $(\delta=4.60 \mathrm{ppm})$ were chosen for the calculation of the percentage conversion of terpene alcohol, according to the following equation: \% Ester conversion $=[E /(A+E)] \times$ 100 , where $E$ and $A$ represent the results of the integration of methylene protons of diester and nerol, respectively [30].

The final conversion of nerol and carboxylic groups were shown in Table 1. The physical properties of diesters: density, viscosity, and refractive index were presented in Table 2.

\section{Analytical methods}

Proton nuclear magnetic resonance $\left({ }^{1} \mathrm{H}\right.$ NMR) spectra were obtained using an NMR Brucker-Avance 300 MSL

Table 3 TG-DTG data of linear neryl diesters in inert atmosphere

\begin{tabular}{lllllll}
\hline Diester & $\begin{array}{l}T_{5} \% / \\
{ }^{\circ} \mathrm{C}\end{array}$ & $\begin{array}{l}T_{10} \% / \\
{ }^{\circ} \mathrm{C}\end{array}$ & $\begin{array}{l}T_{20} \% \\
{ }^{\circ} \mathrm{C}\end{array}$ & $\begin{array}{l}T_{50} \% \\
{ }^{\circ} \mathrm{C}\end{array}$ & $\begin{array}{l}T_{\max 1} / \\
{ }^{\circ} \mathrm{C}\end{array}$ & $\begin{array}{l}\mathrm{RM} / \\
\%\end{array}$ \\
\hline $\begin{array}{c}\text { Dineryl } \\
\text { succinate }\end{array}$ & 198 & 215 & 234 & 259 & 268 & 4.66 \\
$\begin{array}{c}\text { Dineryl } \\
\text { glutarate }\end{array}$ & 205 & 223 & 242 & 274 & 285 & 4.70 \\
$\begin{array}{c}\text { Dineryl } \\
\text { adipinate }\end{array}$ & 222 & 235 & 255 & 280 & 294 & 8.93 \\
$\begin{array}{c}\text { Dineryl } \\
\text { sebacinate }\end{array}$ & 240 & 254 & 272 & 297 & 322 & 10.23 \\
\hline
\end{tabular}

$R M$ residual mass at $700{ }^{\circ} \mathrm{C}$

Table 4 DSC data of linear neryl diesters in inert atmosphere

\begin{tabular}{lllll}
\hline Diester & $T_{\text {onset }} /{ }^{\circ} \mathrm{C}$ & $T_{\text {peak }} /{ }^{\circ} \mathrm{C}$ & $T_{\text {end }} /{ }^{\circ} \mathrm{C}$ & $\Delta H / \mathrm{Jg}^{-1}$ \\
\hline Dineryl succinate & 286 & 293 & 299 & 412.9 \\
Dineryl glutarate & 290 & 296 & 299 & 253.2 \\
Dineryl adipinate & 296 & 301 & 305 & 182.4 \\
Dineryl sebacinate & 306 & 310 & 317 & 175.8 \\
\hline
\end{tabular}

(Germany) spectrometer at $300 \mathrm{MHz}$ with deuterated chloroform $\left(\mathrm{CDCl}_{3}\right)$ as the solvent. ${ }^{1} \mathrm{H}$ NMR chemical shifts in parts per million (ppm) were reported downfield from $0.00 \mathrm{ppm}$ using tetramethylsilane as an internal reference.
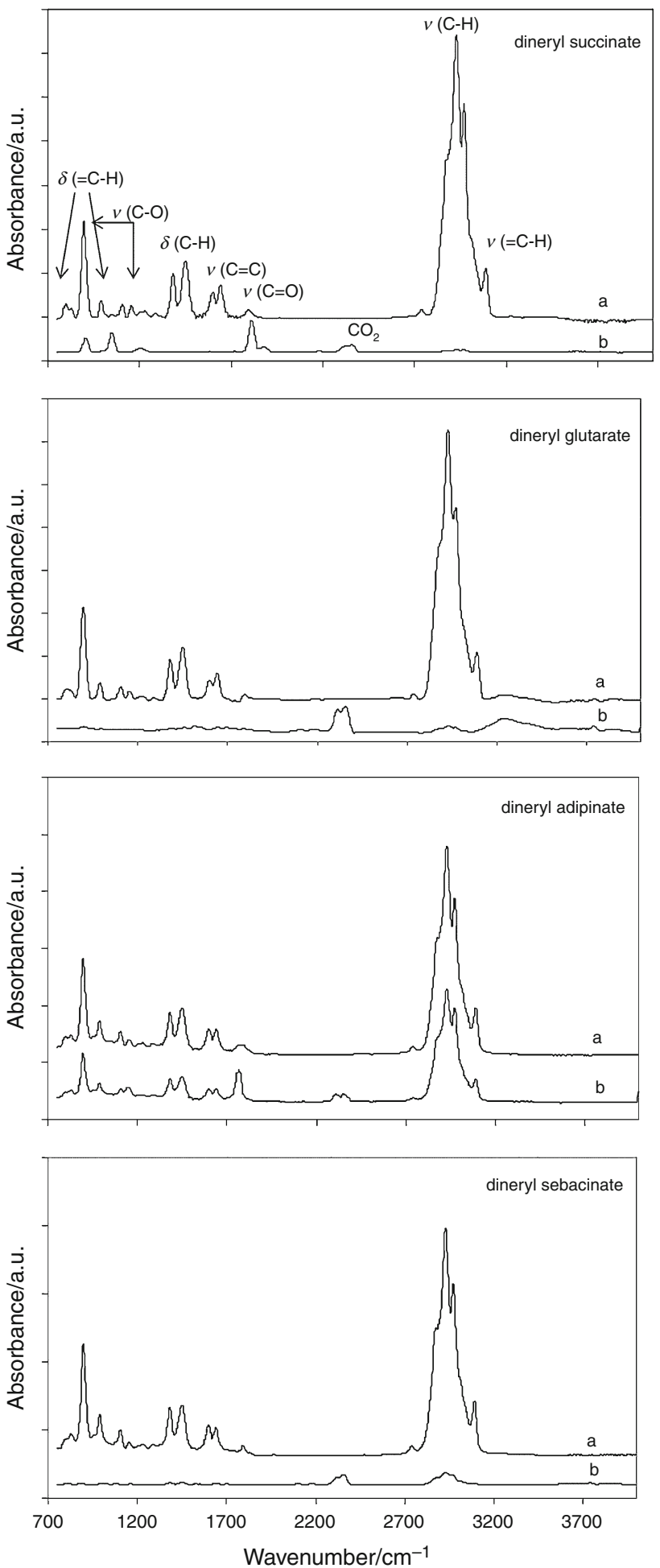

Fig. 5 IR spectra of the gases related during the decomposition of linear neryl diesters in inert atmosphere 

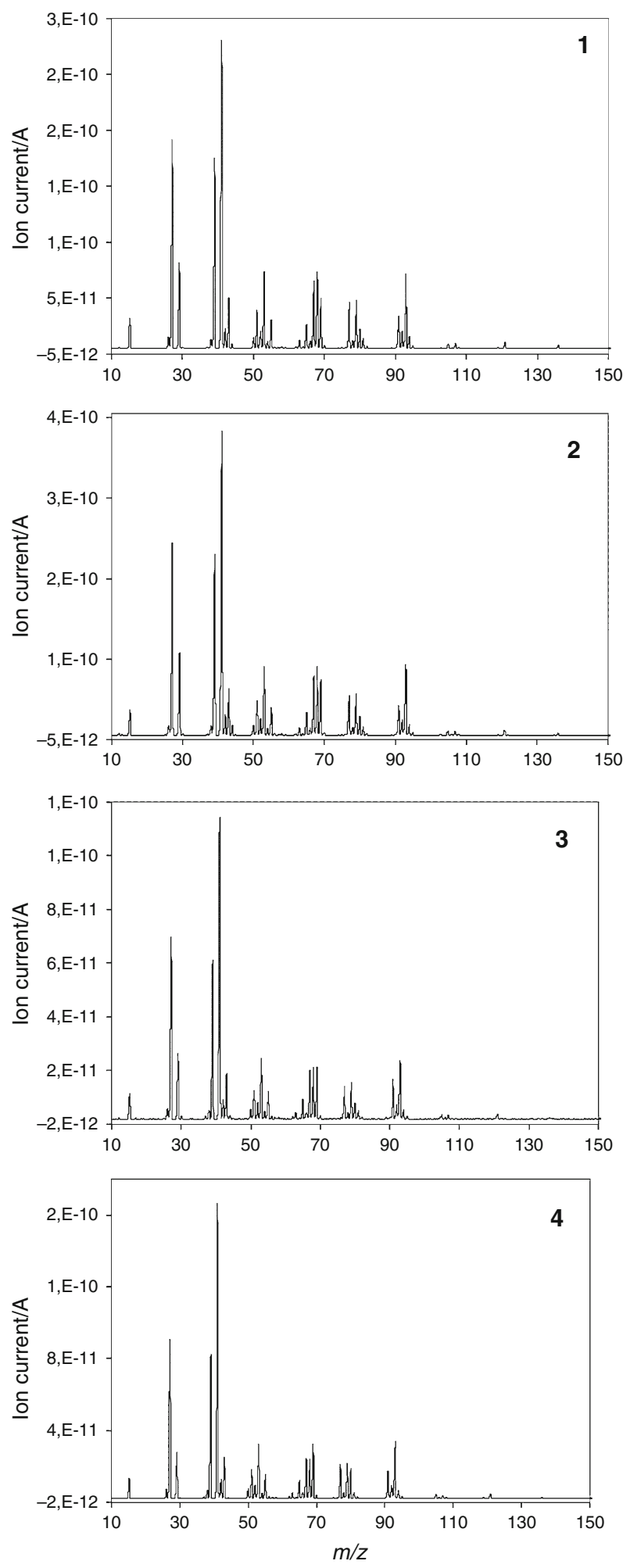

Fig. 6 QMS spectra of the gases related during the decomposition of linear neryl diesters in inert atmosphere

Attenuated total reflection were recorded using infrared Fourier transform spectroscopy on spectrometer Brucker TENSOR 27, equipped with diamond crystal (Germany).
The spectra were recorded in the spectral range of $600-4,000 \mathrm{~cm}^{-1}$ with 16 scans per spectrum at a resolution of $4 \mathrm{~cm}^{-1}$.

${ }^{13} \mathrm{C}$ NMR spectra were recorded on a Brucker $300 \mathrm{MSL}$ instrument (Germany). Chemical shifts were referred to chloroform serving as an internal standard.

Viscosity was measured by means of rotating spindle rheometer at $25^{\circ} \mathrm{C}$, Brookfield, model DV-III (Germany).

Density was evaluated using a glass pycnometer with capillary fuse Gay/Lussac $(25 \mathrm{~mL})$ at $23{ }^{\circ} \mathrm{C}$.

Refractive index was determined by refractometer Carl Zeis Jena at $23{ }^{\circ} \mathrm{C}$.

Acid number $\left(\mathrm{mgKOH} \mathrm{g}{ }^{-1}\right)$ was evaluated by titration of the sample against potassium hydroxide using phenolphthalein as an indicator and acetone as a solvent.

Thermal analysis was carried out on a STA 449 Jupiter F1, Netzsch (Germany) under the following operational conditions: heating rate of $10{ }^{\circ} \mathrm{C} \mathrm{min}^{-1}$, a dynamic atmosphere of helium $\left(40 \mathrm{~mL} \mathrm{~min}^{-1}\right)$ or synthetic air $\left(40 \mathrm{~mL} \mathrm{~min}^{-1}\right)$, temperature range of $40-700{ }^{\circ} \mathrm{C}$, sample mass $\sim 10 \mathrm{mg}$, sensor thermocouple type $\mathrm{S}$ TG-DSC. As a reference empty $\mathrm{Al}_{2} \mathrm{O}_{3}$ crucible was used. The identification of a gas emitted during decomposition process was detected and analyzed by FT IR spectrometer TGA 585 Brucker (Germany) and QMS 403C Aëolos (Germany) coupling on-line to STA instrument. The FTIR spectrometer with IR cell maintained at $200{ }^{\circ} \mathrm{C}$ was connected on-line to STA instrument by Teflon transfer line with diameter of $2 \mathrm{~mm}$ heated to $200{ }^{\circ} \mathrm{C}$. The FTIR spectra were recorded in the spectral range of $650-4,000 \mathrm{~cm}^{-1}$ with 16 scans per spectrum at a resolution of $4 \mathrm{~cm}^{-1}$. The QMS was operated with an electron impact ionizer with energy $70 \mathrm{eV}$. The measurements were performed in scan mode for $m / z$, where $m$ is the mass of molecule and $z$ is a charge of the molecule in electron charge units. The spectra were recorded in the range from 10 to $150 \mathrm{amu}$.

\section{Results and discussion}

Characterization of linear neryl diesters

The final conversion of nerol and carboxylic groups was higher than $95 \%$ after $8-17 \mathrm{~h}$, Table 1 . However, the final conversion of nerol and carboxylic groups was achieved after longer time than that obtained for recently studied geranyl diesters [27]. It was probably connected with the steric hindrance (the cis position of hydroxyl group), and thus to lower susceptibility of nerol to esterification process with anhydrides and acids than geraniol.

Nevertheless, those studies directly confirm that diesters derivatives of nerol can also be obtained with high purity using this method of synthesis. It allows limiting the consumption of substrates, eliminating of strong acid catalysts 
which are responsible for structural rearrangements of terpene alcohol. This preparation method allows increasing the yield of the main product, and thus reducing preparation cost.

The obtained linear neryl diesters are flavor oils, soluble in most of organic solvents but insoluble in water. Their structure was precisely confirmed by FTIR, ${ }^{1} \mathrm{H}$ NMR, and ${ }^{13} \mathrm{C}$ NMR analyses, (Figs. 1, 2, 3), respectively. The basic properties of neryl diesters are placed in Table 2. It is clearly visible that their properties were directly depended on the structure of diesters. The viscosities were in the range from $13 \mathrm{mPas}$ (dineryl succinate) to $38 \mathrm{mPas}$ (dineryl sebacinate) and densities from 0.9850 to almost $1.0020 \mathrm{~g} \mathrm{~cm}^{-3}$, respectively.

\section{TG/FTIR/QMS characterization of linear neryl diesters}

The thermal properties and the mechanism of decomposition of neryl diesters were studied by the TG/FTIR/QMScoupled method in inert atmosphere (helium) and in oxidative atmosphere (synthetic air).

Figure 4 shows the TG, DTG, and DSC curves for studied compounds in inert atmosphere. The temperature of $5,10,20,50 \%$ of mass loss $\left(T_{5} \%, T_{10} \%, T_{20} \%, T_{50}\right)$, the residual mass at $700{ }^{\circ} \mathrm{C}(\mathrm{RM})$, the temperature of the maximum rate of mass loss ( $\left.T_{\max }\right)$ obtained from TG-DTG curves during pyrolysis of diesters were placed in Table 3. Also, the data from DSC curves like the onset $\left(T_{\text {onset }}\right)$, max ( $\left.T_{\text {peak }}\right)$, end $\left(T_{\text {end }}\right)$ temperatures, and the enthalpy of decomposition $(\Delta H)$ of diesters in inert atmosphere were presented in Table 4.
The results indicate that neryl diesters are thermally stable up to temperatures c.a. $200{ }^{\circ} \mathrm{C}$ in helium. Their thermal stability was only a little lower than for previously described geranyl diesters [27]. Also, their decomposition run as a one-step process between temperatures ranges from c.a. 200 to above $340{ }^{\circ} \mathrm{C}$. The mass loss during their pyrolysis was significant. It oscillated between $89.77 \%$ to almost $95.34 \%$. The residual mass at $700{ }^{\circ} \mathrm{C}(\mathrm{RM})$ was from $4.66 \%$ for dineryl succinate to $10.23 \%$ for dineryl sebacinate. In addition, the DSC curves also show one endothermic peak corresponding to the mass loss displayed by the TG curves. In addition, the characteristic temperatures obtained from DSC were comparable to those from TG analysis.

Figure 5 presents the IR spectra of gaseous products gathered at $T_{\max 1}$ (a) and $T_{\max 1+5^{\circ} \mathrm{C}}$ (b) during pyrolysis of diesters. The presence of the signals for stretching $(v \mathrm{C}-\mathrm{H})$ and deformation $(\delta \mathrm{C}-\mathrm{H})$ vibrations characteristic for methyl and methylene groups are indicated. The appearance of absorption signals responsible for stretching $(v=\mathrm{C}-\mathrm{H}, v \mathrm{C}=\mathrm{C})$ and deformation $(\delta=\mathrm{C}-\mathrm{H})$ vibrations of alkene groups are observed. The signals for stretching vibrations $(v)$ for $\mathrm{C}=\mathrm{O}$ and $\mathrm{C}-\mathrm{O}$ groups are also indicated $[31,32]$. Those results may suggest the formation of an acyclic and alicyclic monoterpene hydrocarbons, cyclic anhydrides, ketones, or aldehydes fragments during the pyrolysis of neryl diesters.

Additionally performed TG/QMS analysis directly confirmed the results obtained based on TG/FTIR. The MS spectra of gaseous products emitted at $T_{\max 1}$ are shown in Fig. 6. The probable route for the decomposition of studied
Scheme 1 The probable route for the decomposition of neryl diesters in helium

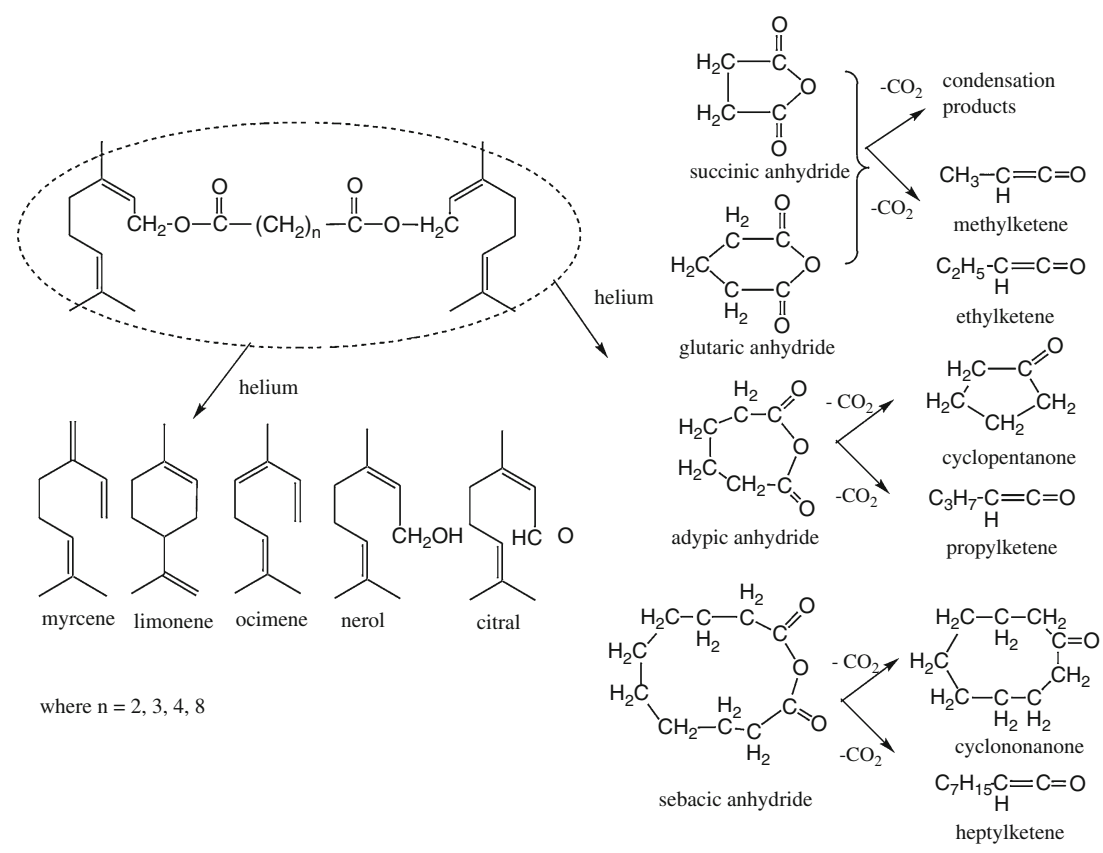


compounds in inert atmosphere is presented in Scheme 1. This analysis directly confirmed that during pyrolysis of neryl diesters various decomposition products are emitted. Regarding the structure of studied compounds, the most probable decomposition products are myrcene $(\mathrm{m} / \mathrm{z}=41$, $93,69,39,27)$, limonene $(m / z=68,93,39,67,41)$, ocimene $(\mathrm{m} / \mathrm{z}=93,41,79,91,77)$, and citral $(\mathrm{m} / \mathrm{z}=41,69$, $27,39,84)$ for all compounds during pyrolysis. In addition among the decomposition products of dineryl succinate and dineryl glutarate one can find the cyclic acid anhydrides, e.g., succinic anhydride $(m / z=28,56,26,27)$ and glutaric anhydride $(\mathrm{m} / \mathrm{z}=42,70,44,41,27)$, respectively. The partial decarboxylation process of acid anhydrides is also
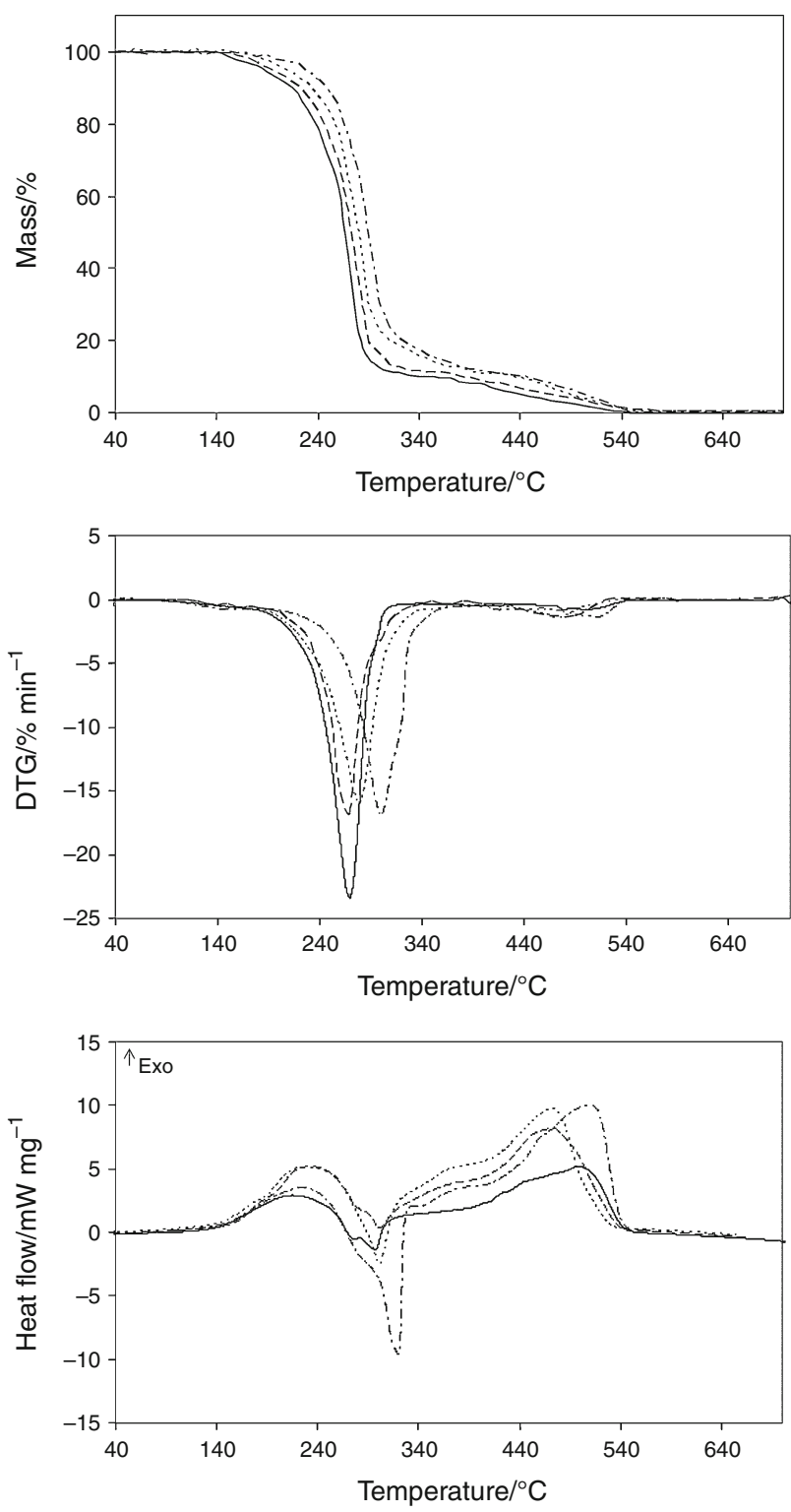

Fig. 7 TG, DTG, and DSC curves in oxidative atmosphere for linear neryl diesters: dineryl succinate (1), dineryl glutarate (2), dineryl adipinate (3), dineryl sebacinate (4) possible. It causes the formation of condensation products, cyclic ketones or ketene fragments. The most probable pyrolysis products of dineryl adipinate and dineryl sebacinate are cyclic ketones fragments $(\mathrm{m} / \mathrm{z}=42,41,56,27,39$ and $m / z=55,41,42,56,27$ ) [32]. Those results were in accordance with our previous studies. The type of decomposition products indicated on the asymmetrical disrupt of the bonds. The cleavage of the ester and O-neryl bonds were suspected. It confirmed that the decomposition process on neryl diesters proceeds according to the same path as for geranyl diesters in helium [27].

However, the thermal properties of studied compounds in oxidative atmosphere were considerable different from those obtained in inert atmosphere. The TG, DTG, and DSC curves and the data collected in air are presented in Fig. 7, Tables 5 and 6 , respectively.

The thermal decomposition process of neryl diesters in air atmosphere run in two steps. The first, main decomposition step is visible in the temperature ranges from c.a. $185-228{ }^{\circ} \mathrm{C}$ to almost $326-380{ }^{\circ} \mathrm{C}$ with $T_{\max 1}$ from 269 to $302{ }^{\circ} \mathrm{C}$. In the first step the mass loss was above $88 \%$. The second stage was observed in temperatures from 380 to above $560{ }^{\circ} \mathrm{C}$ with $T_{\max 2}$ from 479 to $511{ }^{\circ} \mathrm{C}$. The mass loss was about $10-12 \%$ in this step. The DSC analysis shows three peaks. The first, exothermic peak is situated from c.a. $140{ }^{\circ} \mathrm{C}$ with maximum temperature at $215-233{ }^{\circ} \mathrm{C}\left(T_{\text {peak } 1}\right)$. It is directly connected with the oxidation process of studied compounds. The second one is endothermic $\left(T_{\text {peak } 2}\right)$. Their presence and position indicate

Table 5 TG-DTG data of linear neryl diesters in oxidative atmosphere

\begin{tabular}{llllllll}
\hline Diester & $\begin{array}{l}T_{5} \% / \\
{ }^{\circ} \mathrm{C}\end{array}$ & $\begin{array}{l}T_{10} \% \\
{ }^{\circ} \mathrm{C}\end{array}$ & $\begin{array}{l}T_{20} \% \\
{ }^{\circ} \mathrm{C}\end{array}$ & $\begin{array}{l}T_{50} \% \\
{ }^{\circ} \mathrm{C}\end{array}$ & $\begin{array}{l}T_{\max 1} / \\
{ }^{\circ} \mathrm{C}\end{array}$ & $\begin{array}{l}T_{\max 2} / \\
{ }^{\circ} \mathrm{C}\end{array}$ & $\begin{array}{l}\mathrm{RM} / \\
\%\end{array}$ \\
\hline $\begin{array}{c}\text { Dineryl } \\
\text { succinate }\end{array}$ & 185 & 218 & 240 & 264 & 269 & 487 & 0.03 \\
$\begin{array}{c}\text { Dineryl } \\
\text { glutarate }\end{array}$ & 193 & 220 & 245 & 263 & 270 & 490 & 0.05 \\
$\begin{array}{c}\text { Dineryl } \\
\text { adipinate }\end{array}$ & 210 & 232 & 258 & 275 & 278 & 479 & 0.08 \\
$\begin{array}{c}\text { Dineryl } \\
\text { sebacinate }\end{array}$ & 228 & 250 & 263 & 296 & 302 & 511 & 0.10 \\
\hline
\end{tabular}

$R M$ residual mass at $700{ }^{\circ} \mathrm{C}$

Table 6 DSC data of linear neryl diesters in oxidative atmosphere

\begin{tabular}{llll}
\hline Diester & $\begin{array}{l}T_{\text {peak } 1} /{ }^{\circ} \mathrm{C} \\
\text { exo })\end{array}$ & $\begin{array}{l}T_{\text {peak } 2} /{ }^{\circ} \mathrm{C} \\
(\text { endo })\end{array}$ & $\begin{array}{l}T_{\text {peak3 }} /{ }^{\circ} \mathrm{C} \\
(\text { exo })\end{array}$ \\
\hline Dineryl succinate & 215 & 297 & 510 \\
Dineryl glutarate & 233 & 302 & 475 \\
Dineryl adipinate & 227 & 302 & 472 \\
Dineryl sebacinate & 225 & 319 & 511 \\
\hline
\end{tabular}



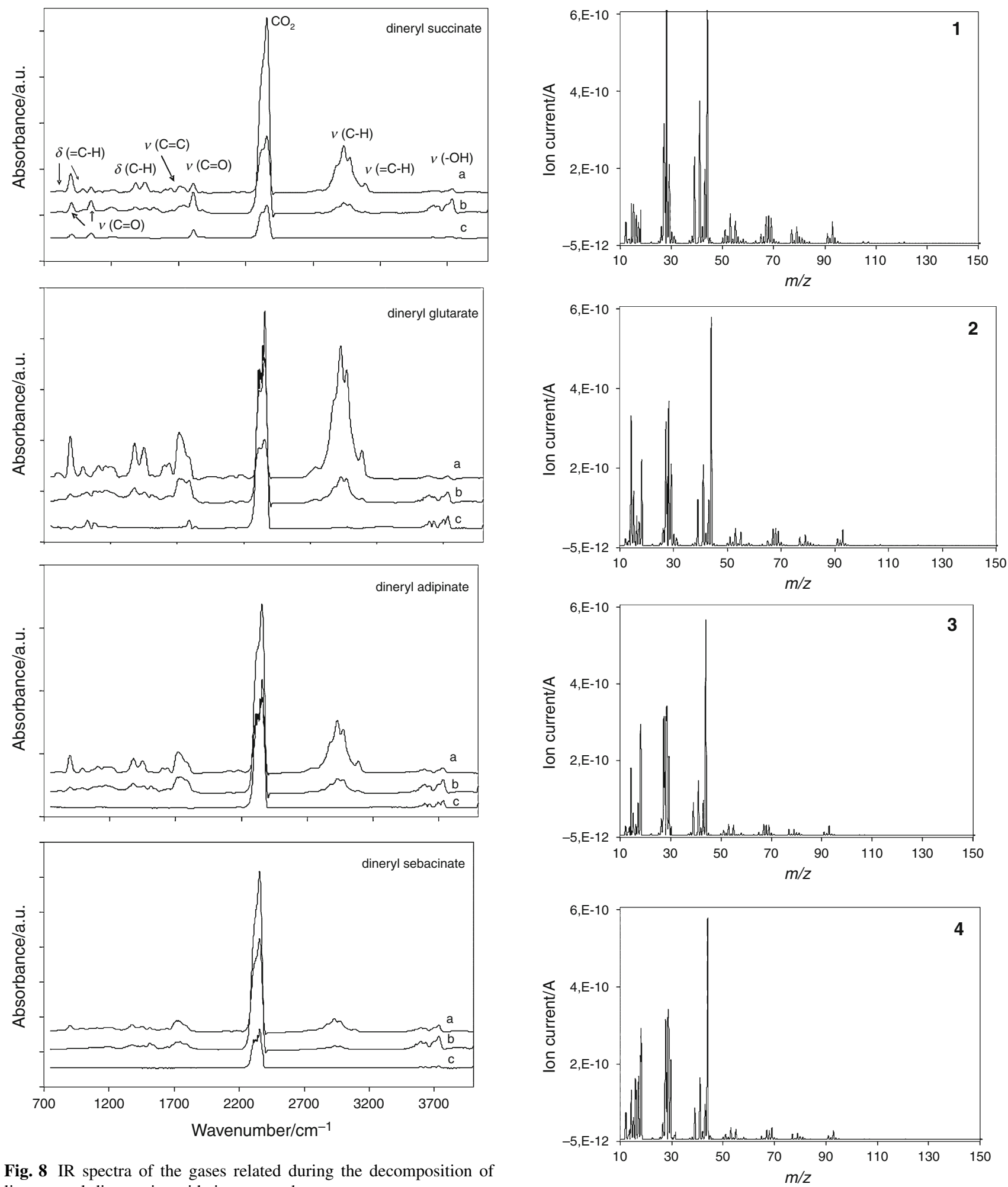

Fig. 8 IR spectra of the gases related during the decomposition of linear neryl diesters in oxidative atmosphere

on the occurrence of the first decomposition step. The DSC results were in agreement with those obtained from TG analysis. The third peak is non-symmetrical, exothermic, and it spreads from 360 to above $550{ }^{\circ} \mathrm{C}$. The position of this signal is in accordance with the position of the

Fig. 9 QMS spectra of the gases related during the decomposition of linear neryl diesters in oxidative atmosphere

degradation peak on DTG curves. Probably, it is the result of oxidation process of the residue formed after the main decomposition step of studied compounds. 
Scheme 2 The probable route for decomposition of neryl diesters in air

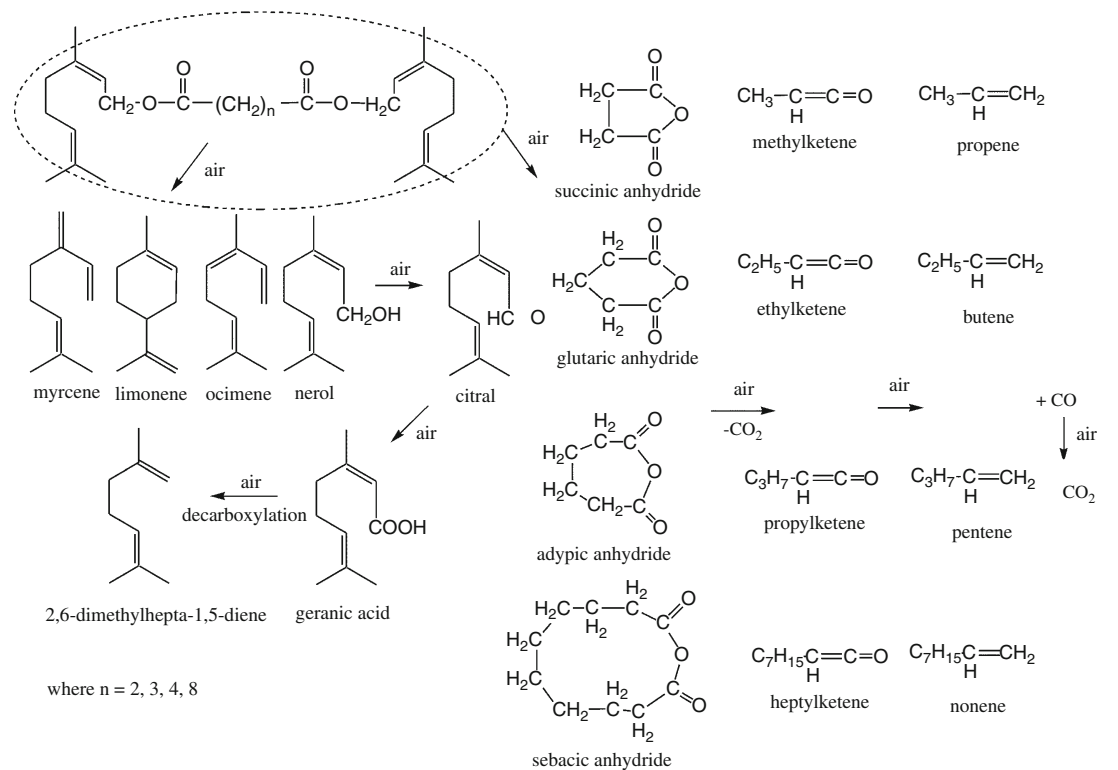

The FTIR spectra of gaseous products emitted at $T_{\max 1}$ (a), $T_{\max 1+5^{\circ} \mathrm{C}}$ (b) and $T_{\max 2}$ (c) during heating in air are presented in Fig. 8. The appearance of strong absorption signals at 2,329-2,358 $\mathrm{cm}^{-1}$ characteristic for carbon dioxide was indicated. Also, the signals at $3,600-3,740 \mathrm{~cm}^{-1}$ (stretching vibration of $-\mathrm{OH}$ ) connected with the presence of carboxylic groups or water during the first step was observed [21, 33-35]. The stretching $(v \mathrm{C}-\mathrm{H})$ and deformation $(\delta \mathrm{C}-\mathrm{H})$ vibrations which are related to methylene and methyl groups at $1,367-1,440$ and at $2,870-2,980 \mathrm{~cm}^{-1}$ are visible. Also, the stretching $(v \mathrm{C}=\mathrm{C}, v=\mathrm{C}-\mathrm{H})$ and deformation $(\delta=\mathrm{C}-\mathrm{H})$ vibrations characteristic for $-\mathrm{CH}=\mathrm{CH}_{2}$ and $>\mathrm{C}=\mathrm{CH}_{2}$ groups at $1592-1630,828-990$, and $3,082 \mathrm{~cm}^{-1}$ are present. The stretching vibrations at $1,704-1,803$ and $1,093-1,187 \mathrm{~cm}^{-1}$ connected with the vibrations of $\mathrm{C}=\mathrm{O}$ and $\mathrm{C}-\mathrm{O}$ groups are also detected [31, 32].

The QMS results gathered at $T_{\max 1}$ in oxidative atmosphere are presented in Fig. 9. The probable route for the decomposition of studied diesters in oxidative atmosphere is presented in Scheme 2. The main decomposition products based on the obtained results are acyclic and alicyclic monoterpene hydrocarbons like myrcene $(\mathrm{m} / \mathrm{z}=41,93$, $69,39,27)$, limonene $(m / z=68,93,39,67,41)$, ocimene $(\mathrm{m} / \mathrm{z}=93,41,79,91,77)$, citral $(\mathrm{m} / \mathrm{z}=41,69,27,39$, 84 ), and their decarboxylation form: 2,6-dimethylhepta1,5 -diene $(\mathrm{m} / \mathrm{z}=68,67,41,39,109)$. However, also the formation of cyclic acid anhydrides, ketones $(\mathrm{m} / \mathrm{z}=43$, $58,15,42,27)$ and its derivatives, e.g., ketenes, alkenes $(m / z=41,39,42,27,40, m / z=43,56,55,41,69)$, or alkanes $(\mathrm{m} / \mathrm{z}=28,27,30,26,29$ or $\mathrm{m} / \mathrm{z}=16,15,14,13$, 12) [32] are expected during applied conditions. Those results indicated on the asymmetrical distrupt of the bonds, partial oxygenation, and decarboxylation of emitted gaseous fragments.
The TG/FTIR/QMS analysis confirmed that in the second decomposition step mainly the production of carbon dioxide and water is observed. It testifies to oxidation process of the residue formed during the first decomposition step.

\section{Conclusions}

The results confirmed that linear neryl diesters can be successfully obtained during butylstannoic acid catalyzed esterification process. The final conversion of nerol and carboxylic groups was higher than $95 \%$ using a stoichiometric molar ratio of reagents in mild conditions. The high yield products were prepared after longer time than previously studied geranyl diesters. It was directly connected with the steric hindrance and lower susceptibility of nerol to esterification process than geraniol.

The TG/FTIR/QMS studies proved that the thermal properties and decomposition mechanism of neryl diesters differ considerably in inert and oxidative atmosphere. The flavor compounds were thermally stable up to $200{ }^{\circ} \mathrm{C}$ in inert atmosphere. Their decomposition was run as a one-step process with $T_{\max 1} 268$ to $322{ }^{\circ} \mathrm{C}$. The analyses of the volatile products emitted during pyrolysis of neryl diesters indicated on the same decomposition mechanism as for geranyl diesters. The ester and O-neryl bonds cleavage was suspected. It resulted in the formation of monoterpene hydrocarbons, cyclic acid anhydrides, ketones, and aldehydes fragments.

However, diesters were less thermally stable in air than in helium. Their decomposition happened in two steps. The first step ranges from 185 to $228^{\circ} \mathrm{C}$ to almost $326-380{ }^{\circ} \mathrm{C}$ with mass loss above $88 \%$. The formation of acyclic or alicylic monoterpene hydrocarbons, cyclic acid anhydrides, 
ketones, alkenes, alkanes, carbon dioxide, and water was observed. It indicated on the asymmetrical distrupt of the bonds, partial oxygenation and decarboxylation of emitted gaseous fragments. The second step of decomposition was observed in temperatures ranges from 380 to above $560{ }^{\circ} \mathrm{C}$. In this step carbon dioxide and water were mainly emitted. It was the result of the oxidation of the residue formed during the fist step.

Open Access This article is distributed under the terms of the Creative Commons Attribution License which permits any use, distribution, and reproduction in any medium, provided the original author(s) and the source are credited.

\section{References}

1. Cardillo P, Gigante L, Lunghi A, Zanirato P. Revisiting the thermal decomposition of five ortho-substituted phenyl azides by calorimetric techniques. J Therm Anal Calorim. 2010;100:191-8.

2. de Cássia da Silva R, Semaan FS, Novák C, Cavalheiro ETG. Thermal behavior of furosemide. J Therm Anal Calorim. 2011;. doi:10.1007/s10973-011-2058-8.

3. Bolbukh Y, Tertykh V, Klonos P, Pissis P. DSC study of polyhydroxyethylmethacrylate filled with modified silicas. J Therm Anal Calorim. 2012;108:1111-9.

4. Fulias A, Vlase G, Grigorie C, Ledeți I, Albu P, Bilanin M, Vlase T. Thermal behaviour studies of procaine and benzocaine. J Therm Anal Calorim. 2013; doi:10.1007/s10973-013-2959-9.

5. Babiński P, Łabojko G, Kotyczka-Morańska M, Plis A. Kinetics of coal and char oxycombustion studied by TG-FTIR. J Therm Anal Calorim. 2013;. doi:10.1007/s10973-013-3002-x.

6. Czylkowska A, Markiewicz M. Synthesis, thermal behavior, and other properties of $\mathrm{Y}(\mathrm{III})$ and $\mathrm{La}(\mathrm{III})$ complexes with $4,4^{\prime}$ bipyridine and trichloro- or dibromoacetates. J Therm Anal Calorim. 2012;109:727-34.

7. Grochowicz M, Gawdzik B, Jaćkowska M, Buszewski B. Investigation of the thermal behavior of new silica-polymer anion exchangers. J Therm Anal Calorim. 2012;. doi:10.1007/s10973012-2635-5.

8. Mocanu AM, Odochian L, Apostolescu N, Moldoveanu C. TGFTIR study on thermal degradation in air of some new diazoaminoderivatives. J Therm Anal Calorim. 2010;100:615-22.

9. Hardy A, Van Werde K, Vanhouland G, Van Bael MK, Mullens J, Van Poucke LC. Study of the decomposition of an aqueous metal-chelate gel precursor for $(\mathrm{Bi}, \mathrm{La}) 4 \mathrm{Ti} 3 \mathrm{O} 12$ by means of TGA-FTIR, TGA-MS and HT-DRIFT. Thermochim Acta. 2003; 397:143-53.

10. Jang BN, Wilkie CA. A TGA/FTIR and mass spectral study on the thermal degradation of bisphenol A polycarbonate. Polym Degrad Stab. 2004;86:419-30.

11. Liu Y, Yi YS, Cai XF. The investigation of intumescent flameretarded polypropylene using poly(hexamethylene terephthalamide) as carbonization agent. J Therm Anal Calorim. 2012;107: 1191-7.

12. Cervantes-Uc JM, Cauich-Rodriguez JV, Vázquez-Torres H, Licea-Claverie A. TGA/FTIR study on thermal degradation of polymethacrylates containing carboxylic groups. Polym Degrad Stab. 2006;91:3312-21.

13. Arockiasamy A, Toghiani H, Oglesby D, Horstemeyer MF, Bouvard JL, King RL. TG-DSC-FTIR-MS study of gaseous compounds evolved during thermal decomposition of styrenebutadiene rubber. J Therm Anal Calorim. 2013;111:35-542.
14. Ahamad T, Alshehri SM. Thermal degradation and evolved gas analysis of epoxy (DGEBA)/novolac resin blends (ENB) during pyrolysis and combustion. J Therm Anal Calorim. 2013;111:445-51.

15. Popescu LM, Piticescu RM, Stoiciu M, Vasile E, Trusca R. Investigation of thermal behaviour of hybrid nanostructures based on $\mathrm{Fe}_{2} \mathrm{O}_{3}$ and PAMAM dendrimers. $J$ Therm Anal Calorim. 2012;. doi:10.1007/s10973-012-2352-0.

16. Małecka B, Łącz A, Małecki A. TG/DTA/MS/IR study on decomposition of cadium malonate hydrates in inert and oxidative atmosphere. J Anal Appl Pyrolysis. 2007;80:126-33.

17. Madarász J. Evolved gas analyses on a mixed valence copper (I, II) complex salt with thiosulfate and ammonia by in situ TGEGA-FTIR and TG/DTA-EGA-MS. J Therm Anal Calorim. 2009;97:111-6.

18. Małecka B. Thermal decomposition of $\mathrm{Cd}\left(\mathrm{CH}_{3} \mathrm{COO}\right)_{2} \cdot 2 \mathrm{H}_{2} \mathrm{O}$ studied by a coupled TG-DTA-MS method. J Therm Anal Calorim. 2004;78:535-44.

19. Caires FJ, Lima LS, Carvalho CT, Ionashiro M. Thermal behavior of succinic acid, sodium succinate and its compounds with some bivalent transition metal ions. Thermochim Acta. 2010;500:6-12.

20. Czylkowska A. New complexes of heavy lanthanides with $4,4^{\prime}$ bipyridine and trichloroacetates. J Therm Anal Calorim. 2012; 110:1299-308.

21. Mocanu AM, Odochian L, Apostolescu N, Moldoveanu C. Comparative study on thermal degradation of some new diazoamidoderivatives under air and nitrogen atmosphere. J Therm Anal Calorim. 2011;103:283-91.

22. Liu X, Gu S, Xu W. Thermal and structural characterization of superfine down powder. J Therm Anal Calorim. 2013;111:259-66.

23. Liu Z, Fei B, Jiang Z, Cai Z, Yu Y, Liu X. A comparative study of thermal properties of sinocalamus affinis and moso bamboo. J Therm Anal Calorim. 2013;111:393-9.

24. Kaljuvee T, Keelman M, Trikkel A, Petkova V. TG-FTIR/MS analysis of thermal and kinetic characteristics of some coal samples. J Therm Anal Calorim. 2013; doi:10.1007/s10973-013-2957-y.

25. Zhou S, Ning M, Xu Y, Shu J, Wang Ch, Hu Y, Ge S, Tian Z, She $\mathrm{S}, \mathrm{He} \mathrm{Q}$. Effects of melamine phosphate on the thermal decomposition and combustion behavior of reconstituted tobacco sheet. J Therm Anal Calorim. 2012;. doi:10.1007/s10973-012-2674-y.

26. Saponar A, Popovici EJ, Perhaita I, Nemes G, Cadis AI. Thermal behaviour of some ester derivatives of $p$-tert-butyl calix $[n]$ arene. J Therm Anal Calorim. 2012;110:349-56.

27. Worzakowska M, Ścigalski P. TG/DSC/FTIR characterization of linear geranyl diesters. J Therm Anal Calorim. 2013;113:56-60.

28. Gildemeister E, Hoffmann FR. The volatile oils. New York: Wiley; 1913.

29. Bauer K, Garbe D, Surburg H. Common fragrance and flavor materials: preparation, properties and uses. New York: Wiley; 2001. p. 43-5.

30. Patil D, Das D, Nag A. Enzymatic synthesis and analytical monitoring of terpene ester by ${ }^{1} \mathrm{H}$ NMR spectroscopy. Chem Pap. 2011;65:9-15.

31. Sokrates G. Infrared and Raman characteristic group frequencies, tables and charts. New York: Wiley; 2001. p. 157-67.

32. NIST chemistry webbook standard reference database number 69 , 2011, http://webbook.nist.gov/chemistry.

33. Ionashiro EY, Caires FJ, Siqueira ABS, Lima LS, Carvalho CT. Thermal behaviour of fumaric acid, sodium fumarate and its compounds with light trivalent lanthanides. J Therm Anal Calorim. 2012;108:1183-8.

34. Cai GM, Yu WD. Study on the thermal degradation of high performance fibers by TG/FTIR and Py-GC/MS. J Therm Anal Calorim. 2011;104:757-63.

35. Shi J, Wang Z, Liu Y, Wang C. Investigation of thermal behavior of enoxacin and its hydrochloride. J Therm Anal Calorim. 2012;108:299-306. 